\title{
Digital Scales of Web-Based Partograph in Detecting the Early Postpartum Bleeding
}

\author{
Sry Wahyuni ${ }^{1}$, Mardiana Ahmad ${ }^{1}$, Syafruddin Syarif ${ }^{1,2}$, Nasrudin A. Mappaware ${ }^{1,3}$, \\ Prihantono $^{1,4}$ \& Burhanuddin Bahar ${ }^{1,5}$ \\ ${ }^{1}$ Postgraduate Program, Department of Midwifery, Hasanuddin University, Makassar, South Sulawesi, Indonesia \\ ${ }^{2}$ Department of Electrical Engineering, Hasanuddin University, Makassar, South Sulawesi, Indonesia \\ ${ }^{3}$ Medical Faculty, Universitas Muslim Indonesia, Makassar, South Sulawesi, Indonesia \\ ${ }^{4}$ Deparment of Surgery, Faculty of Medicine, Hasanuddin University, Makassar, South Sulawesi, Indonesia \\ ${ }^{5}$ Faculty of Public Health, Department of Nutrition, Hasanuddin University, Makassar, South Sulawesi, Indonesia \\ Correspondence: Sry Wahyuni, Postgraduate Program, Department of Midwifery, Hasanuddin University, \\ Makassar, South Sulawesi, 90245, Indonesia. Tel: 62-813-4226-2034. E-mail: sriwahyuni11111989@gmail.com
}

Received: March 25, 2019 Accepted: April 22, 2019 Online Published: May 5, 2019

doi:10.5539/gjhs.v11n6p86 URL: https://doi.org/10.5539/gjhs.v11n6p86

\begin{abstract}
Introduction: A simple graph partograph serves to record the information of the inpartu mothers during their 1st active phase of labor, to detect complications, to make an appropriate action in decision making, to prevent prolonged labor, postpartum hemorrhage, and sepsis. The aimof this research was to compare the use of digital scales of web-based partograph and the conventional partograph in detecting the early estimation of postpartum bleeding at the stage III and IV.

Materials and Methods: The study used the Quasi-Experiment method.Thirty women in labor were chosen by using the purposive sampling technique. The web digital scale and the conventional digital scale were used to weigh the underpad of the postpartum at the stage III and IV. The Independent T-test and Mann-Whitney test were employed to analyze the data.

Results: The results of the study indicated that the digital scale of the WEB-based partograph was more rapid in estimating the postpartum hemorrhage at the stage III and IV comparing to the digital scale of conventional partograph. The statistical test of Mann-Whitney revealed the $p$-value $>0.05$, which means that there was a difference in the speed but in case of the accuracy aspect of p-value $>0.05$, it means that there was no difference. In case of the estimation of the blood amount at stage III and IV, the test value of the Independent T-test revealed the $p$-value of $>0.05$, which means that there was no difference in the estimation of the postpartum hemorrhage.
\end{abstract}

Conclusion: It was concluded that the digital scale of web-based partograph was faster in estimating postpartum hemorrhage at period III and IV comparing to the digital scales of conventional partograph and there were no differences in its accurateness and number of postpartum hemorrhage at the stage III and IV.

Keywords: partograph, web, scale, conventional, hemorrhage

\section{Introduction}

Partograph isthe simple graphs which function to record the information of inpartu women during their $1^{\text {st }}$ active phase of labor, and it is also used as a tool which can detect the complications in order to take an appropriate action in decision making. Thus, it can reduce the Maternal Mortality Rate (MMR). The first partograph was introduced by Friedman in 1950, then developed and redesigned by Philpott and Puri in 1971 by adding the concept of warning and action lines (Archa Prem 2013; Gitanjali, 2016; Sinha, 2016; Opoku \& Nguah, 2015; Akpan, 2014; Mathibe Neke \& Matupa, 2013; Yisma,2013; Hasan, 2017; Fatouh \& Ramadan, 2015; Suchika et al., 2014; Mandiwa \& Zamawe, 2017; Nwaneri et al., 2017; Bedwell, Levin, Pett, \& Lavender,2017; Zelellw, 2016; Okokon et al., 2014; Pusparinda, 2015; Markos \& Bogale, 2015).

World Health Organization (WHO) states that the appropriate use of partograph can improve the labor management, decision making, prevent prolonged labor, postpartum hemorrhage and sepsis (Abebe, 2013). Furthermore, the odds ratio 3 means that the occurance of stillbirths increase three times if the partograph is not 
used and managed properly, Thus it is necessary to develop the tool (Ashish, Wrammert, Clark, Ewald, \& Malqvist, 2016).

WHO reported that there were about 289,000 of maternal deaths in 2013.Common causes of death were postpartum hemorrhage (64\%), hypertension (15.62\%), and (6.25\%) pulmonary embolism (Kumar \& Agrawal, 2016).

Postpartum hemorrhage is the loss of more than $500 \mathrm{cc}$ of blood after childbirth. It is related to the main causes of maternal death include uterine atony (50-60\%), residual placenta (23-24\%), placental retention (16-17\%) birth canal lacerations (4-5\%) (Solomon, 2012; Pavol Zubor et al., 2014; Smith et.al., 2014; Francoise, Chloe, Bruno Pereir, Didier, \& The Hera Group, 2016; Rousseau et al., 2016).

Monitoring at the stage III plays an important role in preventing the bleeding during labor, and it is also related to the knowledge and skills of health workers in providing services. The results of the study in Ethiopia about the use of partograph showed that the health workers, in terms of having good knowledge were at $53.4 \%$ and sufficient knowledge were at $26 \%$. The percentages were related with the use of partograph sheets atthe second stage of labor, active management at the third stage which is very important in preventing bleeding around $60-70 \%$, including administration of oxytocin, controlled cord stretching and uterine fundal massage. Furthermore, monitoring the IV stage until 2 hours of postpartum include: pulse, blood pressure, bladder, temperature, and bleeding period is the most urgent thing to prevent maternal and infant mortality (Adnan, 2017; Rani \& Begum, 2017; Sentilhes et al., 2015; Egenberg, 2017; Guasch \& Gilsanz, 2016; Herrick, Mvundura, Burke, \& Abu-Haydar,2017; Nyflot et al., 2017; Francoise et al.,2016; Mobeen et al., 2010; Mezmur, 2017; Mandiwa, 2017; Zalalem, 2017).

In the past, people measured the estimation of postpartum hemorrhage by using a cloth which covered by blood, buttocks, and glove. After that people weighed it manually. Previously, the estimation of blood loss was only estimated by birth attendants or visually which was not necessarily accurate.Putri yayu et al., (2018) found that computer-based partograph is more effective than conventional partograph in terms of clinical decision-making andaction. Moreover, TrisnaYunita et al., (2018) found that the speed of the computer-based partograph in filling were at 8.6 hours comparing to the conventional partograph which only took 11.6 hours. Thus, the authors developed the Web-based paragraph application for early detection of hemorrhage postpartum at stage III and IV. The authors developed additional digital scales which is connected to computers or laptops with web-based partograph which includes weighing underpad which is placed under the mother's butt in every 15 minutes and then it weighed on the first hour, and 30 minutes in the second hour of postpartum so that the observation of postpartum for 2 hours can help the midwifery to provide fast and accurate services in order to reduce maternal morbidity and mortalilty (Montufar-Rueda, 2013; Nwaneri et al., 2017; Fatouh \& Ramadan, 2015).

\section{Materials and Methods}

\subsection{Study Design and Sample Population}

The design used in this study is Quasi-Experiment design by giving the treatment to the participants. This study was conducted at the Primary health care of Antang Perumnas and Bara-Baraya Makassar starting from November 2018 to January 2019. The sample was 30 women in labor by using purposive sampling techniques, data collection primary, univariate and bivariate analysis such as the Independent T-test and Mann Whitney statistical tests. The authors also used tools such as computers, software, printers, underpads, digital web scales, conventional digital scales, gloves, stopwatches, and Wi-Fi.

The population in this study was all of the mothers at the Primary health care of Antang Perumnas and BaraBaraya Makassar. Adopting Wilcoxon sum table with minimum sample of 5, the authors were used half of the population but in this case, due to the accurate results of this study, the number of the sample was 30 who used digital web scale and conventional digital scale. The sampling technique used by authors was purposive sampling because the subject of the research was determined based on the authors' requirement. The criterion of the subject such as the inclusion criteria was the women who experienced a normal laborat the stage III and IV, meanwhile the exclusion criteria included the women in labor who experienced complications. 


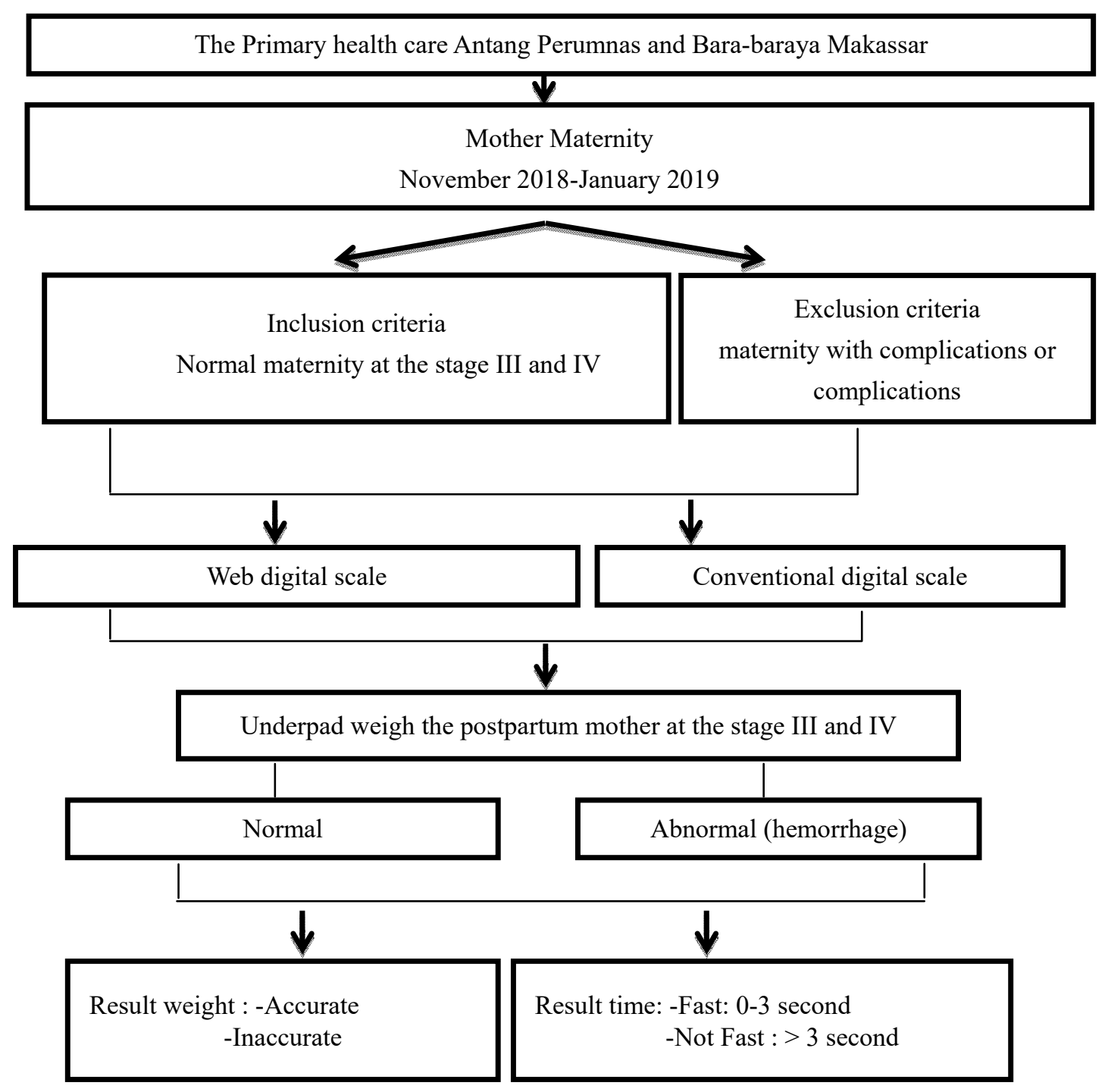

Figure 1. The flowchart of the Study

\subsection{Data Collection}

Primary data were obtained by conducting interviews, observation and documentation based on the sources needed. The underpad was weightby using digital web scales and conventional digital scales. The results were recorded both in a documentary sheet which starting from postpartum at the stage III to IV and a stopwatch was also used to calculate the speed of scales.

\subsection{Ethical Considerations}

The study followed the ethical clearance from the Research and Ethics Committee of the Medical Faculty of Hasanuddin University and was registered 905 / H4.8.4.5.31 / PP36-KOMETIK / 2018

\subsection{Data Management and Analysis}

The processing of the data used univariate and bivariate analysis and the results were displayed in the form of narration and frequency distribution of tables. The bivariate analysis used an independent T-test to accurately assess the results of the scales and Mann Whitney test in assessing the accuracy speed in displaying the results of the scales. Moreover, the data analysis of this study used SPSS version 24. 


\section{Results}

\subsection{Analysis Univariate}

Table 1.Age of respondents

\begin{tabular}{lll}
\hline Variables & $\mathbf{N}$ & $\mathbf{\%}$ \\
\hline$<20$ years & 4 & 13.3 \\
$20-35$ years & 21 & 70.0 \\
$>35$ years & 5 & 16.0 \\
Total & 30 & 100 \\
\hline
\end{tabular}

Source: Primary Data.

Table 2. Characteristics of parity

\begin{tabular}{lll}
\hline Variables & $\mathbf{N}$ & $\mathbf{\%}$ \\
\hline Primigravida & 8 & 26.7 \\
Multigravida & 21 & 70.0 \\
Grandemultigravida & 1 & 3.3 \\
Total & 30 & 100 \\
\hline
\end{tabular}

Source: Primary Data.

Table 3. The comparison between the speed and accurateness of digital scales in web-based partograph and conventional digital scales for early detection of estimation of postpartum hemorrhage at the stages III and IV

\begin{tabular}{lll}
\hline Variables at Stage III and IV & N & p-value \\
\hline Web and digital scales & 30 & .000 \\
Accurateness of web and digital scales & 30 & 1.000 \\
\hline
\end{tabular}

Mann Whitney.

Table 4. The comparison between the amount of blood in digital scales of web-based partograph and conventional digital scales for early detection of estimation of postpartum hemorrhage at the stage III

\begin{tabular}{llc}
\hline Variables at stage III & N & p-Value \\
\hline Amount of blood in Web and digital scales & 30 & .929 \\
\hline
\end{tabular}

Independent T-test.

Table 5. The comparison between the amount of blood in digital scales of web-based partograph and conventional digital scales for early detection of estimation of postpartum hemorrhage at the stage IV

\begin{tabular}{lll}
\hline Variable atstage IV & N & p-Value \\
\hline & & .699 \\
& .666 \\
Amount of blood in Web and digital scales & .557 \\
& 30 & .984 \\
& & .951 \\
\hline
\end{tabular}

Independent T-test.

\section{Discussion}

The patients in this study involved 4 people who were in $<20$ years $(13.3 \%), 21$ people who were in 20-35 years $(70 \%)$, and 5 people who were in $>35$ years $(16.7 \%)$. The maternal parity is 8 people who experienced 
primigravida (26.7\%), 21 people who experienced multigravida $(70 \%)$, and 1 person who experienced grandemultigravida (3.3\%). The age is related to the readiness of the mother in reproduction. $<20$ years old women were still in the stage of growth and development, so that the condition of their pregnancy made her have to share the nutrition with their fetus. Conversely, > 35 years old women began to show the influence of the aging process such as hypertension, diabetes mellitus, which can prevent the entrance of the food for fetus through the placenta. Meanwhile, women who experienced multigravida became weaker in their uterus and it can cause complications since they were more often experiences pregnancy, parturition or $>3$ times of parturition. The highest parity is one of the risk factors for postpartum hemorrhage because it tends to experience uterine atony. So it can be concluded that the average of maternal age around 20-35 years were still healthy and safe in reproducing, meanwhile parity in multigravida were at a risk category because they have given birth more than twice or $>3$ times (Pratami, 2013).

The results of the data analysis using the Mann Whitney Test in terms of speed with a p-value .000 value or $<0.05$ means that there were significant differences, in terms of accurate aspects with p-value values of 1,000 or $>0.05$ means that there were no significant differences in digital scales of web-basedpartograph and conventional digital scales. In the past, measuring the estimation of postpartum hemmorhage was using visual birth attendants and did not use other measurements that were not necessarily accurate, so the authors developed a tool to calculate the estimation number of postpartum hemorrhage by using digital scales that was connected in the web-based partograph. The digital scales in the web-based partograph has Esp8266 d1 uno which is used to process the scales in the number of grams of the data that will be sent to Esp8266 d1 mini which functions as a receiver of the data and it is sent forward to the web-based partograph which is calculated in milliliters (ml).

Thus, it can help the health workers in knowing the speed of the postpartum hemmorhage estimation at the stage III and IV, so that early detection of postpartum emergency such as loss of more than $500 \mathrm{cc}$ of blood after child birth (Hancock, Andrew, \& Dame, 2015; Underwood, Sterling, \& Bennett, 2012). This digital scale can help people to avoid postpartum hemorrhage, to improve the diagnosis and the management strategies. The digital scale that is connected to a web-based partograph are able to provide an early detection and to help in making decision in terms of the emergency cases during labor, a postpartum hemorrhage and a sepsis that must be referred immediately (Souza et al., 2015; Markos \& Bogale, 2015; Abebe, 2013). Wilde (2009) found that the faster the health worker in detecting the problem, the better the impact on patients in terms of payment, complications, morbidity, mortality, prevention and treatment.

The estimation of postpartum hemorrhage at the stage III and IV showed that the p-value at $>0.05$. It means that there were no significant differences between digital scales in web-based partograph and conventional digital scales in terms of the accuracy. Both scales measured the instruments that have the same density and its accuracy that has been calibrated. In other words, it can be said accurate if a measuring instrument is able to measure what should be measured and using digital scales has a better level of accuracy as well as the operation is more efficient than the analog scales (Edwar, Boni, \& Muh, 2016).

The results of the data analysis using the Independent T-test on digital scales in web-based partograph and in the estimation of postpartum hemmorhage at the stage III obtained p-value .929 or $>0.05$. It can be interpreted as insignificant or no differences. Basically, the web-based partograph which was developed by combining with the digital scalesand it was also connected to the web-based partograph system is the first design obtained by the authors and has not been previously available in facilitating health workers, especially midwives. It helps them in measuring the estimation of postpartum hemorrhage at the stage III by weighing the underpad which contains the blood during stage III in order to find out the results quickly and accurately. This way can be used as an alternative choice to facilitate health workers, especially midwives in knowing the exact amount of blood loss, quickly and accurately, without having to guess the amount of blood visually (Carvalho, Gilda, Daniel, Mariana, \& Metin, 2018; Hancock et al., 2015; Sloan, Durocher, Aldrich, Blum, \& Winikoff, 2010). Thus, the midwives can carry on the postpartum emergency immediately and preventthe mothersto experience what is commonly called 3T; being late in making decision, being late in processing the referral, and being late to get the treatment (Egenberg et al., 2017).

The analysis of the independent T-test on digital scales in web-based partograph and on the estimation of the amount postpartum hemmorhage at the stage IV showed the entire amount of the first blood to the sixth blood with $\mathrm{p}$-value $>0.05$. In other words, there were no significant differences between the amounts of first blood to the amount of the sixth blood on digital web scales and digital scales. This means that these two scales produced the results of the blood that are significantly different in statistical tests, although in reality there were still differences. These differences were not quite meaningful in a statistical test before the digital scales in the web-based 
partograph were made in the calibration with a standardized gold standard. Partograph which is designed by using the web-based digital scales are the development of computer-based partograph that are effective in the speed, convenience and relevance of the data in clinical decision making (Putri yayu et al., 2018).

\section{Conclusion}

The digital scale in web-based partograph is faster in measuring the estimation of postpartum hemorrhage at the stage III and IV comparing with the conventional digital scales. In terms of accurateness and measuring the amount of blood in postpartum hemorrhage at the stage III and IV hemorrhage, the digital scale in web-based partograph can help the midwives to treat the patient who experienced bleeding.

\section{Acknowledgements}

The authors would like to say thank to the Head of Antang Perumnas Health Center and the Head of Bara-Baraya Health Center, Head of Administration, Administrative Staffs, Midwives in the maternity room and the Research Team for their humility in helping and motivating the authors during the research.

\section{Competing Interests Statement}

The authors declare that there are no competing or potential conflicts of interest.

\section{References}

Abebe, F. (2013). Assessment of knowledge and utilization of the partograph among health professionals in Amhara region, Ethiopia. Science Journal of Clinical Medicine, 2(2), 26-42. https://doi.org/10.11648/j.sjcm.20130202.11

Adnan, N. (2017). Intramuscular oxytocin versus intravenous oxytocin to prevent postpartum haemorrhage at vaginal delivery (Labor trial): Study protocol for a randomised controlled trial (Department of Obstetrics and Gynacologi, Biomed Central). https://doi.org/10.1186/s13063-017-2269-9

Akpan, U. (2014). Assessment of the Knowledge and Utilization of the Partograph among Non-physician Obstetric Care Givers in the University of Calabar Teaching Hospital, Calabar, Nigeria. British Journal of Medicine \& Medical Research, 4. https://doi.org/10.9734/BJMMR/2014/10853

Archa Prem, S. M. V. (2013). Effectiveness of Individual Teaching on Knowledge Regarding. International Journal of Recent Scientific Research Research, 4(7), 1163-1166, July, 2013.

Ashish, K. C., Wrammert, J., Clark, R. B., Ewald, U., \& Målqvist, M. (2016). Inadequate fetal heart rate monitoring and poor use of partogram associated with intrapartum stillbirth: a case-referent study in Nepal. BMC pregnancy and childbirth, 16(1), 233.https://doi.org/10.1186/s12884-016-1034-5

Bedwell, C., Levin, K., Pett, C., \& Lavender, D. T. (2017). A realist review of the partograph: when and how does it work for monitoring labor? BMC Pregnancy Childbirth, 17, 31. https://doi.org/10.1186/s12884-016-1213-4

Carvalho, J., Gilda, P., Daniel, W., Mariana, W., \& Metin, G. (2018). Distribution of postpartum blood loss: Modeling,estimationand application to clinical trial. Reproductive Health, 15, 199. https://doi.org/10.1186/s12978-018-0641-1

Edwar, F., Boni, P., \& Muh, I. (2016). RancangBangunTimbangan Digital Berbasis Sensor Beban $5 \mathrm{Kg}$ MenggunakanMikrokontrolerAtmega328, Positron, Prodi Fisika. FMIPA UniversitasTanjungpura, Jalan Prof. Dr. HadariNawawi, Pontianak (Vol. VI, No. 1 (2016), Hal. 23 - 28).

Egenberg, S. (2017). Impact of multi-professional, scenariobased training on postpartum hemorrhage in Tanzania: a quasi-experimental, pre-vs.post-interventionstudy. BMC Pregnancy and Childbirth, 17, 287. https://doi.org/10.1186/s12884-017-1478-2

Fatouh, E., \& Ramadan, S. (2015). Effect of Using Paperless Partogram on the Management and Outcome of Labour and the Nurses' Opinion. Journal of Education and Practice, 6(8), 17-23.

Francoise, V., Chloe, B., Bruno Pereir, A., Didier, L., \& The Hera Group. (2016). Rencidence of immediate postpartum hemorrhages in French maternity units: A prospective observational study (HERA study). BMC Pregnancy and Childbirth, 16, 242. https://doi.org/10.1186/s12884-016-1008-7

Gitanjali, D. (2016). Role of Paperless Partograph in MonitorinPrimiparous and Multiparous Labour. IJHRMLP, 2(2), 2016

Guasch, E., \& Gilsanz, F. (2016). Treatment of Postpartum Hemorrhage with Blood Products in a Tertiary Hospital: Outcomes and Predictive FactorsAssociated with Severe Hemorrhage. Thrombosis/Hemostasis, 22(7), 
685-692. https://doi.org/10.1177/1076029615573303

Hancock, A., Andrew, D., \& Dame, T. (2015). Accurate and reliable blood loss estimation the 'crucial step' in early detection of postpartum haemorrhage: an integrative review of the literature. BMC Pregnancy and Childbirth,) 15, 230. https://doi.org/10.1186/s12884-015-0653-6

Hasan, M. J. (2017). Comparative Analysis of Life Curve Mobile Application: an Easier Alternative to Existing Traditional Paper Partograph. Journal of Mobile Computing \& Application, 4. IOSR Journal of Mobile Computing \& Application (IOSR-JMCA). https://doi.org/10.9790/0050-04015561

Herrick, T., Mvundura, M., Burke, T. F., \& Abu-Haydar, E. (2017). A low-cost uterine balloon tamponade for management of postpartum hemorrhage: modeling the potential impact on maternal mortality and morbidity in sub-Saharan Africa. BMC pregnancy and childbirth, 17(1), 374. https://doi.org/10.1186/s12884-017-1564-5

Kumar, A., \& Agrawal, N. (2016). Brought in dead: an avoidable delay in maternal deaths. The Journal of Obstetrics and Gynecology of India, 66(1), 60-66. https://doi.org/10.1007/s13224-015-0762-1

Mandiwa, C., \& Zamawe, C. (2017). Documentation of the partograph in assessing the progress of labor by health care providers in Malawi's South-West zone. Reproductive Health, 14, 134. https://doi.org/10.1186/s12978-017-0401-7

Markos, D., \& Bogale, D. (2016). Knowledge and utilization of partograph among health care professionals in public health institutions of Bale zone, Southeast Ethiopia. Public Health, 137, 162-8. https://doi.org/10.1016/j.puhe.2016.02.026

Mathibe Neke, L. F., \& Matupa, B. (2013). The partograph: A labor management tool or a Midwifery record? International Journal of Nursing and Midwifery, 5(8), 145-153. https://doi.org/10.5897/IJNM2013.0115

Mezmur, H., Semahegn, A., \&Tegegne, B. S. (2017). Health professional's knowledge and use of the partograph in public health institutions in eastern Ethiopia: A cross-sectional study. BMC Pregnancy Childbirth, 17, 291. https://doi.org/10.1186/s12884-017-1477-3

Mobeen, N., Durocher, J., Zuberi, N. F., Jahan, N., Blum, J., Wasim, S., ... \& Hatcher, J. (2011). Administration of misoprostol by trained traditional birth attendants to prevent postpartum haemorrhage in homebirths in Pakistan: a randomised placebo-controlled trial. BJOG: An International Journal of Obstetrics \& Gynaecology, 118(3), 353-361. https://doi.org/10.1111/j.1471-0528.2010.02807.x

Nwaneri, A., Ndie, E. C., Ehiemere, I., Okafor, E., Ezenduka, P. O., \& Emeh, A. (2017). Assessment of Client/Center Admimistrative Factors That Affect Nurses' Utilization of Partograph in Primary/Secondary Health Care Facilities in Enugu Metropolis. https://doi.org/10.9790/1.959-0602032630

Nyflot, L. T., Sandven, I., Stray-Pedersen, B., Pettersen, S., Al-Zirqi, I., Rosenberg, M., ... \& Vangen, S. (2017). Risk factors for severe postpartum hemorrhage: a case-control study. BMC pregnancy and childbirth, 17(1), 17. https://doi.org/10.1186/s12884-016-1217-0

Okokon, I. B., Oku, A. O., Agan, T. U., Asibong, U. E., Essien, E. J., \& Monjok, E. (2014). An evaluation of the knowledge and utilization of the partogragh in primary, secondary, and tertiary care settings in Calabar, South-South Nigeria. International journal of family medicine, 2014. https://doi.org/10.1155/2014/105853

Opoku, B. K., \& Nguah, S. B. (2015). Utilization of the modified WHO partograph in assessing the progress of labour in a metropolitan area in Ghana. Research Journal of Women's Health, 2(1), 2. https://doi.org/10.7243/2054-9865-2-2

Pratami, E. (2013). EvidenbasedalamkebidananKehamila, persalinandan Nifas. Jakarta: EGC.

Pusparinda, D. L. A. (2015). The Use of Partogram in Cesarean Section.

Putri, Y., Syarif, S., Ahmad, M., Manyu, B., \& Isharya, S. (2018). Effectiveness OfPartograph Based On Computer System With Clinical Decision Making In Labor Process. International Journal of ChemTech Research, 11(5), 369-375. http://dx.doi.org/10.20902/IJCTR.2018.110541

Rani, P. R., \& Begum, J. (2017). Recent advances in the management of major postpartum haemorrhage-A Review. Journal of clinical and diagnostic research: JCDR, 11(2), QE01. https://doi.org/10.7860/JCDR/2017/22659.9463

Rousseau, A., Rozenberg, P., Perrodeau, E., Deneux-Tharaux, C., \& Ravaud, P. (2016). Variations in postpartum hemorrhage management among midwives: A national vignette-based study. PloS one, 11(4), e0152863. 
https://doi.org/10.1371/journal.pone.0152863

Sentilhes, L., Daniel, V., Darsonval, A., Deruelle, P., Vardon, D., Perrotin, F., ... \& Deneux-Tharaux, C. (2015). Study protocol. TRAAP-TRAnexamic Acid for Preventing postpartum hemorrhage after vaginal delivery: A multicenter randomized, double-blind, placebo-controlled trial. BMC pregnancy and childbirth, 15(1), 135. https://doi.org/10.1186/s12884-015-0573-5

Sinha, D., Shrivastava, S., \& Shrivastava, S. (2016). Management of Labour in Primigravida with Who Modified Partograph. Scholars Journal of Applied Medical Sciences, 4, 3457-3461. https://doi.org/10.21276/sjams.2016.4.9.5

Sloan, N. L., Durocher, J., Aldrich, T., Blum, J., \& Winikoff, B. (2010). What measured blood loss tells us about postpartum bleeding: a systematic review. BJOG: An International Journal of Obstetrics \&Gynaecology, 117(7), 788-800. https://doi.org/10.1111/j.1471-0528.2010.02567.x

Smith, J. M., Baawo, S. D., Subah, M., Sirtor-Gbassie, V., Howe, C. J., Ishola, G., ... \& Dwivedi, V. (2014). Advance distribution of misoprostol for prevention of postpartum hemorrhage (PPH) at home births in two districts of Liberia. BMC pregnancy and childbirth, 14(1), 189. https:// doi.org/10.1186/1471-2393-14-189

Solomon, C. (2012). Haemostatic monitoring during postpartum haemorrhage and implications for management. British Journal of Anaesthesia, 109(6), 851-63. https://doi.org/10.1093/bja/aes361

Souza, J. P., Oladapo, O. T., Bohren, M. A., Mugerwa, K., Fawole, B., Moscovici, L., ... \& Tunçalp, Ö. (2015). The development of a simplified, effective, labour monitoring-to-action (SELMA) tool for better outcomes in labour difficulty (BOLD): study protocol. Reproductive health, 12(1), 49. https://doi.org/10.1186/s12978-015-0029-4

Suchika, G., Usha, S., Premlata, M., \& Madhu, M. (2014). To Study the Fetomaternal Outcome and Progress of Labour among Induced versus Spontaneous Labour in Nulliparous Women (Using Modified WHO Partograph). Sch. J. App. Med. Sci., 2(5A), 1577-1580.

TrisnaYulianti, N., Syafruddin, S., Ahmad, M., Manyu, B., \& Sunarno, I. (2018).Comparasionpartograf based on computer system and partografconvensional on monitoring record report progres of labor. International Journal of ChemTech research, 11(05), 363-368. https://doi.org/10.20902/IJCTR.2018.110540

Underwood, H., Sterling, S. R., \& Bennett, J. K. (2012, October). Improving maternal labor monitoring in Kenya using digital pen technology: a user evaluation. In 2012 IEEE Global Humanitarian Technology Conference (pp. 282-287). IEEE. https://doi.org/10.1109/GHTC.2012.77

Wilde, E. (2009). Do emergency Medical System Response Time Matter For Health Outcome?. New York: Colombia University.

Yisma, E., Dessalegn, B., Astatkie, A., \& Fesseha, N. (2013a). Completion of the modified World Health Organization (WHO) partograph during labor in public health institutions of Addis Ababa, Ethiopia.Reproduktive Health, 10, 23. https://doi.org/10.1186/1742-4755-10-23

Yisma, E., Dessalegn, B., Astatkie, A., \& Fesseha, N. (2013b). Knowledge and utilization of partograph among obstetric care givers in public health institutions of Addis Ababa, Ethiopia. BMC Pregnancy Childbirth, 13, 17. https://doi.org/10.1186/1471-2393-13-17

Zalalem, T. (2017). Providers of obstetric care, knowledge, and related factors to the active management of the third stage of labor in Sidama Zone, South Ethopia. BMC Pregnancy and Childbirt.

Zelellw, D. A. (2016). Knowledge and Attitude of Obstetric Care Providers on Partograph and Its Associated Factors in East Gojjam Zone, Northwest Ethiopia. https://doi.org/10.1155/2016/6913165

Zubor, P., Kajo, K., Dokus, K., Krivus, S., Straka, L., Bodova, K. B., \& Danko, J. (2014). Recurrent secondary postpartum hemorrhages due to placental site vessel subinvolution and local uterine tissue coagulopathy. BMC pregnancy and childbirth, 14(1), 80. https://doi.org/10.1186/1471-2393-14-80

\section{Copyrights}

Copyright for this article is retained by the author(s), with first publication rights granted to the journal.

This is an open-access article distributed under the terms and conditions of the Creative Commons Attribution license (http://creativecommons.org/licenses/by/4.0/). 